\title{
Nutritional plans on the intake, digestibility, and performance of dairy heifers of different breed compositions
}

\author{
Carlos Alberto Alves Oliveira Filho(1), Fernanda Samarini Machado(2), Alexandre Lima Ferreira(2), \\ Thierry Ribeiro Tomich ${ }^{(2)}$, Rogério Martins Maurício(3), Mariana Magalhães Campos ${ }^{(2)}$, Camilla Flávia \\ Portela Gomes da Silva ${ }^{(4)}$, José Augusto Gomes de Azevêdo(5) and Luiz Gustavo Ribeiro Pereira(2)
}

\begin{abstract}
(1)Universidade Estadual do Sudoeste da Bahia, BR 415, Km 03, s/no, Campus Universitário, CEP 45700-000 Itapetinga, BA, Brazil. E-mail: carlos.uesb@hotmail.com (2)Embrapa Gado de Leite, Avenida Eugênio do Nascimento, o 610, CEP $36038-330$ Juiz de Fora, MG, Brazil. E-mail: fernanda.machado@embrapa.br, axellfire@hotmail.com, thierry.tomich@embrapa.br, mariana.campos@embrapa.br, luiz.gustavo@embrapa.br ${ }^{(3)}$ Universidade Federal de São João del-Rei, Praça Dom Helvécio, no 74, Campus Dom Bosco, CEP 36301-160 São João del Rei, MG, Brazil. E-mail: rogeriomauricio@ufsj.edu.br ${ }^{(4)}$ Instituto Federal de Educação, Ciência e Tecnologia Baiano, BR 420, s/nº, CEP 45320-000 Santa Inês, BA, Brazil. E-mail: camilla.silva@si.ifbaiano.edu.br ${ }^{(5)}$ Universidade Estadual de Santa Cruz, Rodovia Jorge Amado, Km 16, CEP 45662-900 Ilhéus, BA, Brazil. E-mail: zeguto00@gmail.com
\end{abstract}

\begin{abstract}
The objective of this work was to evaluate the effects of nutritional plans and breed composition on nutrient intake and digestibility, nitrogen balance, and performance of dairy heifers in tropical conditions. Thirty-six heifers -12 Holstein, 12 Gyr, and 12 Gyrolando F1 (1/2 Holstein $\times 1 / 2$ Gyr) - were housed in a tie-stall system and randomly distributed, adopting a completely randomized design in a $3 \times 3$ factorial arrangement (nutritional plans and breed composition). The diets were formulated to enable weight gains of 200, 400, and $800 \mathrm{~g}$ per day, corresponding to the nutritional plans 11,14 , and $19 \mathrm{~g} \mathrm{~kg}^{-1}$ body weight (BW), respectively. The intake of dry matter, fibrous fractions $\left(\mathrm{g} \mathrm{kg}^{-1} \mathrm{BW}^{-0.75}\right)$, and metabolizable energy $\left(\mathrm{kcal}^{-1} \mathrm{BW}^{-0.75}\right)$ in the 11- $\mathrm{g} \mathrm{kg}^{-1}$ plan were greater for Gyr heifers than for Gyrolando and Holstein heifers. Ether extract digestibility was $13.85 \%$ higher for Gyr heifers compared with Gyrolando F1 in the $19-\mathrm{g} \mathrm{kg}^{-1}$ plan. The increase in the nutritional plans shows a quadratic response to nutrient intake and a linear response to average daily gain, but does not affect the digestibility coefficients. Gyr and Gyrolando F1 heifers present similar nutritional efficiency to that of Holstein heifers.
\end{abstract}

Index terms: Gyr, Gyrolando, ingestion, nitrogen balance, weight gain.

\section{Planos alimentares no consumo, na digestibilidade e no desempenho de novilhas leiteiras de distintos grupos raciais}

\begin{abstract}
Resumo - O objetivo deste trabalho foi avaliar os efeitos do plano alimentar e do grupo racial sobre o consumo e a digestibilidade de nutrientes, o balanço de nitrogênio e o desempenho de novilhas leiteiras em condições tropicais. Trinta e seis novilhas -12 Holandês, 12 Gir e 12 Girolando F1 ( $1 / 2$ Holandês $\times 1 / 2$ Gir) - foram alojadas em sistema "tie-stall" e distribuídas aleatoriamente, tendo-se adotado delineamento inteiramente casualizado, em arranjo fatorial $3 \times 3$ (planos alimentares e grupos raciais). As dietas foram formuladas para possibilitar ganhos de peso de 200, 400 e $800 \mathrm{~g}$ por dia, correspondentes aos planos alimentares de 11, 14 e $19 \mathrm{~g} \mathrm{~kg}^{-1} \mathrm{de}^{-}$ peso corporal (PC), respectivamente. As novilhas Gir dentro do plano de $11 \mathrm{~g} \mathrm{~kg}^{-1}$ consumiram mais matéria seca, fração fibrosa $\left(\mathrm{g} \mathrm{kg}^{-1}\right.$ de $\left.\mathrm{PC}^{-0,75}\right)$ e energia metabolizável (kcal de $\left.\mathrm{PC}^{-0,75}\right)$ do que as novilhas Girolando e Holandês. A digestibilidade do extrato etéreo foi $13,85 \%$ superior para as novilhas Gir, em comparação às Girolando $\mathrm{F} 1$ no plano de $19 \mathrm{~g} \mathrm{~kg}^{-1}$. $\mathrm{O}$ aumento do plano nutricional tem efeito quadrático no consumo de nutrientes e linear no ganho de peso médio diário, mas não influencia o coeficiente de digestibilidade. Novilhas Gir leiteiras e Girolando F1 apresentam eficiência nutricional semelhante à das novilhas Holandês.
\end{abstract}

Termos para indexação: Gir, Girolando, ingestão, balanço de nitrogênio, ganho de peso.

\section{Introduction}

Monitoring dairy heifer growth rates during the rearing period to optimize efficiency and productivity gains, as well as reducing age at puberty, may represent a strategy to reduce production costs in dairy farming.

The search and adoption of rational measures for the feeding management of ruminant animals, besides 
favoring the efficient use of nutrients by the animal, can generate economic and quality returns in milk production systems, since feeding the herd is the most important cost of production (Collard et al., 2000).

In the third edition of BR-Corte, the Brazilian table of nutritional requirements for pure and crossbred Zebu cattle (Valadares Filho et al., 2016), the prediction of dry matter (DM) intake was increased by $8 \%$ for the Holstein breed and by $4 \%$ for crossbred animals of the Holstein and British breeds, according to the adjustments proposed by Fox et al. (1988) and present in NRC (2000). However, the table does not include information for dairy Zebu animals.

DM intake is the main determinant of animal performance (Waldo \& Jorgense, 1981), and the effect of genotypes on this characteristic has already been shown for at least one of the variables related to intake or performance in dairy cows (Beecher et al., 2014). However, it is not known whether the effect of genotypes on these variables covers all categories of animals, such as growing heifers.

Information on the nutritional and performance parameters of Zebu, Taurine and Crossbred females, reared in tropical conditions, is necessary to determine the nutritive value of diets, energy partition, and nutrition requirements. These data are fundamental for the establishment of nutrition requirements for dairy animals, aiming to guide the formulation of more accurate diets, improving the bioeconomic efficiency of milk production systems.

In Brazil, the animals most adapted to the tropical environment make it possible to produce milk at a lower cost. Although about $80 \%$ of the milk produced in the country comes from cows with the Gyr and Holstein breeds in their genetic composition (Silva et al., 2016), national producers still use data from international committees for the formulation and adjustment of diets, since the available information on the nutritional requirements of Zebu and Crossbred dairy animals is still scarce. Recently, the advances in the investigation of calorimetry-respirometry measurements for dairy cattle (Machado et al., 2016) made it possible to determine nutritional requirements and energy efficiency without the need for animal sacrifice, one of the limiting factors of this type of study due to the high cost of specialized animals for milk production.

The objective of this work was to evaluate the effects of the growth nutritional plans and breed composition on the intake, digestibility, nitrogen balance, and performance of dairy heifers in tropical conditions.

\section{Materials and Methods}

The study was conducted in the bioenergetics laboratory, located at the multi-use complex for livestock bioefficiency and sustainability, of Embrapa Gado de Leite, in Coronel Pacheco, in the state of Minas Gerais, Brazil, from March to September 2014, during 171 consecutive days. All animal care and handling procedures were approved by the ethics committee on animal use of Embrapa Gado de Leite, protocol CEUA-EGL 01/2012.

Thirty-six heifers of different breed composition groups were used: 12 Holstein $(\mathrm{H}), 12 \mathrm{Gyr}(\mathrm{G})$, and 12 Gyrolando F1 (1/2 Holstein $\times 1 / 2$ Gyr). The initial body weight (BWi) was $402 \pm 88,302 \pm 96$, and $456 \pm 79 \mathrm{~kg}$, respectively, for each composition. Throughout the study, heifers were housed in a tie-stall system with free access to water. They were fed a diet consisting of corn silage and concentrate with a forage:concentrate ratio of 707:293 $\mathrm{g} \mathrm{kg}^{-1}$, based on DM (Table 1).

The diet was formulated based on NRC... (2001), for a standard animal with average body weight of $370 \mathrm{~kg}$ and weight gain estimate of $800 \mathrm{~g}$ per day, and was given once daily at 9:00 a.m. A single diet was used, varying only the amount of feed offered to the animals, with proportions of: 11,14 , and $19 \mathrm{~g} \mathrm{~kg}^{-1}$ body weight (BW), which corresponded to the predicted weight gains of 200, 400, and 800 g per day, respectively.

The feed offered and refused was weighed to determine the total daily intake of DM during the experiment. The concentrate ingredients were collected for analysis, and representative samples of silage, concentrate, and orts were collected daily and pooled weekly for the chemical analysis.

During the experimental period, three digestibility trials were performed: at the beginning (53 days), at the middle (102 days), and at the end of the experimental period (151 days). The metabolizable energy (ME, in $\mathrm{Mcal} \mathrm{\textrm {kg } ^ { - 1 }}$ ) of the diets was calculated by the relationship between ME intake (Mcal per day) and DM intake (kg per day). Each digestibility assay lasted eight days: five days of adaptation to the management and three days of total collection of faeces (Rotta et al., 2014).

During the digestibility trials, the urine was collected from all the animals during a 24-hour period, 
on the first and second days of total collection of faeces, using a Folley-type catheter (Valadares et al., 1997). After the second digestibility assay, at 110 days of the experimental period, the procedures to determine the energy loss in the form of methane $\left(\mathrm{CH}_{4}\right)$ by the animals were started, in order to determine the ME of the diet. Two respirometric chambers were used, adopting the procedures and system specifications described by Machado et al. (2016).

The quantification of the energy loss by $\mathrm{CH}_{4}$ production was computed assuming the value of 9.45 kcal L-1 methane (Brouwer, 1965). ME intake was determined by subtracting the gross energy (GE) of faeces, urine, and $\mathrm{CH}_{4}$ from GE intake.

The partition of nitrogenous compounds was calculated by the difference between ingested nitrogen and excreted nitrogen in urine and faeces. Data on the consumption of DM, ME, and nutrients, as well as nitrogen balance were expressed as $\mathrm{kg}$ per day, g per day, kcal per day or Mcal per day, or in units relative to live metabolic weight $(\mathrm{kg} \mathrm{BW})^{-0.75}$.

The intermediate weighings were performed every 15 days, for two consecutive days, always at 7:00 a.m. The mean daily weight gain (MDG) was determined as a function of the 171 experimental days. Feed

Table 1. Formulation and chemical composition of the experimental diet.

\begin{tabular}{|c|c|}
\hline Ingredient & $\mathrm{g} \mathrm{kg}^{-1}$ \\
\hline Corn silage & 707.53 \\
\hline Ground corn & 129.73 \\
\hline Soybean meal & 156.58 \\
\hline Mineral mix $^{(1)}$ & 3.67 \\
\hline $\mathrm{NaCl}$ & 2.49 \\
\hline Chemical composition & $\mathrm{g} \mathrm{kg}^{-1}$ \\
\hline Dry matter & 488.69 \\
\hline Crude protein & 143.76 \\
\hline Ether extract & 40.35 \\
\hline Neutral detergent fiber & 347.84 \\
\hline Acid detergent fiber & 217.61 \\
\hline Non-fibrous carbohydrates & 407.65 \\
\hline Hemicellulose & 130.23 \\
\hline Total carbohydrate & 755.49 \\
\hline Ash & 54.26 \\
\hline \multicolumn{2}{|c|}{ Mcal kg-1 } \\
\hline Gross energy & 4.14 \\
\hline Metabolizable energy & 2.43 \\
\hline
\end{tabular}

efficiency was calculated by the ratio between body weight gain and DM intake.

The following parameters were determined: DM, by method 934.01 (Helrich, 1990); ash, by method 942.05 (Helrich, 1990); crude protein (BW), by method 984.13 (Helrich, 1990); and GE (Cunniff, 1995), all according to Association of Official Analytical Chemists. Neutral detergent fiber (NDF) was obtained by the sequential method of Van Soest et al. (1991), adapted to the conditions of the Ankom 220 apparatus, without the use of sodium sulphite and corrected for residual ash (Mertens, 2002), acid detergent fiber (ADF) (Helrich, 1990), and ether extract (EE) [Helrich (1990), method 920.39]. The correction of NDF and ADF for nitrogen compounds, as well as the estimation of insoluble nitrogen in neutral detergent and acid detergent, followed the recommendations of Licitra et al. (1996).

Data was analyzed as a completely randomized design in a $3 \times 3$ factorial arrangment using the Mixed procedure of SAS, version 9.1.3 (SAS Institute, Cary, NC, USA), according to the model: $\mathrm{Yij}=\mathrm{M}+\mathrm{Cov}+\mathrm{Gi}$ $+\mathrm{Nj}+\mathrm{GNij}+\varepsilon \mathrm{ij}$, where $\mathrm{M}$ is the general mean; Cov is the effect of BWi on the intercept; Gi is the fixed effect of the breed composition group; $\mathrm{Nj}$ is the fixed effect of the food plan; GNij, the fixed effect of the interaction between breed composition and the nutritional plan; and $\varepsilon i j$ is the random error. When the effect of the interaction between breed composition and nutritional plan was significant, decomposition was performed and the averages for the breed composition group factor were compared by Tukey's test, adopting the sum of the squares analysis in orthogonal contrasts related to linear and quadratic effects, at $5 \%$ probability.

\section{Results and Discussion}

A significant interaction between the nutritional plan and breed composition group was observed for $\mathrm{DM}, \mathrm{CP}$, and NDF intake, expressed in kg per day; DM and $\mathrm{NDF}$, in $\mathrm{g} \mathrm{kg}^{-1} \mathrm{BW}^{-0.75}$; and $\mathrm{ME}$, expressed in Mcal per day and kcal (kg BW-0.75) (Table 2).

In the $11-\mathrm{g} \mathrm{kg}^{-1}$ plan, the intake of DM and NDF $\left(\mathrm{g} \mathrm{kg}^{-1} \mathrm{BW}^{-0.75}\right)$ was, respectively, 2.56 and $3.98 \%$; and 2.54 and 3.95\% higher for Gyr heifers compared with Holstein and Gyrolando F1 heifers (Table 3). In this plan, the intake of ME in kcal $\left(\mathrm{kg} \mathrm{BW}^{-0.75}\right)$ by $\mathrm{Gyr}$ heifers was $5.01 \%$ higher than that by Gyrolando F1 heifers. In the 14 and $19-\mathrm{g} \mathrm{kg}^{-1}$ plans, the intakes of DM 
and NDF $\left(\mathrm{g} \mathrm{kg}^{-1} \mathrm{BW}^{-0.75}\right)$ and ME in kcal $\left(\mathrm{kg} \mathrm{BW}^{-0.75}\right)$ did not differ between Holstein, Gyrolando F1, and Gyr heifers.

DM intake is affected by several factors, among which BW is a determining one. Galyean \& Hubbert (1992) observed that BW accounted for $59.8 \%$ of the DM intake variation in diets with net energy for maintenance between 1.0 and $2.4 \mathrm{Mcal} \mathrm{kg}^{-1}$.

In the present study, the ME was $2.43 \mathrm{Mcal} \mathrm{kg}^{-1}$. DM intake $\left(\mathrm{g} \mathrm{kg}^{-1} \mathrm{BW}^{-0.75}\right)$ was higher for Gyr animals in the $11-\mathrm{g} \mathrm{kg}^{-1}$ plan, probably due to their lower initial BW. As the nutritional plans were fixed and heifers were kept under the same environmental and management conditions, the variations found between breed composition groups were lower than $5.1 \%$ for $\mathrm{DM}$, NDF ( $\left.\mathrm{g} \mathrm{kg}^{-1} \mathrm{BW}^{-0.75}\right)$, and ME kcal $\left(\mathrm{kg} \mathrm{BW}^{-0.75}\right)$ intake (Table 3). DM and nutrient intake did not differ between breed composition groups.

Pancoti (2015) reported variation in DM intake of up to $37.02 \%$ in heifers of different genetic groups. Rennó et al. (2005) found variation of up to $27 \%$ when working with young bulls. The lowest variation observed in the present study may be related to the number of animals evaluated $(\mathrm{n}=12$, for each breed composition group), which was higher than the number assessed in the mentioned studies ( $\mathrm{n}=6$ and 4 , respectively). It may also be related to the type of diet (silage $\times$ concentrate) and the different experimental strategies used to change the levels of intake.

The similar values between the breed composition groups for the consumption of DM, CP and NDF (kg per day), DM and NDF ( $\left.\mathrm{g} \mathrm{kg}^{-1} \mathrm{BW}^{-0.75}\right)$, and $\mathrm{ME}$ in kcal $\left(\mathrm{kg} \mathrm{BW}^{-0.75}\right)$, obtained with the 14 and $19-\mathrm{g} \mathrm{kg}^{-1}$ plans (Table 3), indicate that Zebu animals can be nutritionally more efficient under conditions of higher nutritional restriction (nutritional plan with less availability of nutrients). However, in nutritional plans with greater availability of nutrients, Holstein, Gyr, and crossbred animals show similar efficiency.

The quantitative increase in the nutritional plan resulted in a quadratic response for the intakes of: DM, CP, and NDF (kg per day); DM and NDF

Table 2. Intake of dry matter, crude protein, fibrous fraction, and metabolizable energy by Holstein, Gyrolando F1, and Gyr heifers ${ }^{(1)}$.

\begin{tabular}{|c|c|c|c|c|c|c|c|c|c|c|}
\hline \multirow[t]{2}{*}{ Item } & \multicolumn{3}{|c|}{ Nutritional plan $\left(\mathrm{g} \mathrm{kg}^{1}\right)$} & \multicolumn{3}{|c|}{ Breed composition } & \multirow[t]{2}{*}{ SEM } & \multicolumn{3}{|c|}{$\mathrm{p}$-value } \\
\hline & 11 & 14 & 19 & Holstein & F1 & Gyr & & NP & $\mathrm{BC}$ & $\mathrm{NP} \times \mathrm{BC}$ \\
\hline Dry matter (kg per day) & 4.74 & 6.04 & 8.44 & 6.36 & 6.28 & 6.58 & 0.3758 & 0.001 & 0.043 & 0.001 \\
\hline Crude Protein (kg per day) & 0.65 & 0.83 & 1.16 & 0.87 & 0.86 & 0.90 & 0.0517 & 0.001 & 0.042 & 0.001 \\
\hline Neutral detergent fiber (NDF, kg per day) & 1.61 & 2.04 & 2.85 & 2.15 & 2.13 & 2.23 & 0.1272 & 0.001 & 0.034 & 0.001 \\
\hline Metabolizable energy (ME, Mcal per day) & 11.17 & 14.22 & 19.86 & 14.96 & 14.79 & 15.49 & 0.8845 & 0.001 & 0.041 & 0.001 \\
\hline Dry matter $\left(\mathrm{g} \mathrm{kg}^{-1} \mathrm{BW}^{-0.75}\right)$ & 50.29 & 63.19 & 85.01 & 66.20 & 65.78 & 66.51 & 2.6039 & 0.001 & 0.070 & 0.001 \\
\hline $\mathrm{NDF}\left(\mathrm{g} \mathrm{kg}^{-1} \mathrm{BW}^{-0.75}\right)$ & 16.98 & 21.34 & 28.72 & 22.36 & 22.22 & 22.46 & 0.8797 & 0.001 & 0.070 & 0.001 \\
\hline ME kcal $\left(\mathrm{kg} \mathrm{BW}^{-0.75}\right)$ & 117.08 & 146.82 & 199.04 & 153.95 & 153.17 & 155.81 & 6.1781 & 0.001 & 0.042 & 0.0005 \\
\hline
\end{tabular}

SEM, standard error of the mean; NP, nutritional plan; and BC, breed composition group.

Table 3. Sliced interaction of the effect of the breed composition group within the nutritional plan, regarding the intake of dry matter, crude protein, fibrous fraction, and metabolizable energy by Holstein, Gyrolando F1, and Gyr heifers ${ }^{(1)}$.

\begin{tabular}{|c|c|c|c|c|c|c|c|c|c|}
\hline \multirow[t]{2}{*}{ Item } & \multicolumn{3}{|c|}{$11 \mathrm{~g} \mathrm{~kg}^{1}$} & \multicolumn{3}{|c|}{$14 \mathrm{~g} \mathrm{~kg}^{1}$} & \multicolumn{3}{|c|}{$19 \mathrm{~g} \mathrm{~kg}^{1}$} \\
\hline & Holstein & F1 & Gyr & Holstein & F1 & Gyr & Holstein & F1 & Gyr \\
\hline Dry matter (kg per day) & $4.62 b$ & $4.37 \mathrm{~b}$ & $5.25 \mathrm{a}$ & $5.96 \mathrm{a}$ & $5.86 \mathrm{a}$ & $6.30 \mathrm{a}$ & $8.50 \mathrm{a}$ & $8.62 \mathrm{a}$ & $8.10 \mathrm{a}$ \\
\hline Crude protein (kg per day) & $0.63 b$ & $0.60 \mathrm{~b}$ & $0.72 \mathrm{a}$ & $0.82 \mathrm{a}$ & $0.80 \mathrm{a}$ & $0.87 \mathrm{a}$ & $1.17 \mathrm{a}$ & $1.18 \mathrm{a}$ & $1.12 \mathrm{a}$ \\
\hline Neutral detergent fiber (NDF, kg per day) & $1.56 \mathrm{~b}$ & $1.48 \mathrm{~b}$ & $1.78 \mathrm{a}$ & $2.01 \mathrm{a}$ & $1.98 \mathrm{a}$ & $2.13 \mathrm{a}$ & $2.88 \mathrm{a}$ & $2.91 \mathrm{a}$ & $2.77 \mathrm{a}$ \\
\hline Metabolizable energy (ME, Mcal per day) & $10.86 \mathrm{~b}$ & $10.30 \mathrm{~b}$ & $12.36 \mathrm{a}$ & $14.02 \mathrm{a}$ & $13.79 \mathrm{a}$ & $14.84 \mathrm{a}$ & $20.01 \mathrm{a}$ & $20.29 \mathrm{a}$ & $19.28 \mathrm{a}$ \\
\hline Dry matter $\left(\mathrm{g} \mathrm{kg}^{-1} \mathrm{BW}^{-0.75}\right)$ & $50.09 \mathrm{~b}$ & $49.40 \mathrm{~b}$ & $51.37 \mathrm{a}$ & $63.11 \mathrm{a}$ & $62.60 \mathrm{a}$ & $63.85 \mathrm{a}$ & $85.41 \mathrm{a}$ & $85.33 \mathrm{a}$ & $84.30 \mathrm{a}$ \\
\hline $\operatorname{NDF}\left(\mathrm{g} \mathrm{kg}^{-1} \mathrm{BW}^{-0.75}\right)$ & $16.92 b$ & $16.69 \mathrm{~b}$ & $17.35 \mathrm{a}$ & $21.32 \mathrm{a}$ & $21.15 \mathrm{a}$ & $21.57 \mathrm{a}$ & $28.86 \mathrm{a}$ & $28.83 a$ & $28.47 \mathrm{a}$ \\
\hline ME(Mcal per day) & $10.86 \mathrm{~b}$ & $10.30 \mathrm{~b}$ & $12.36 \mathrm{a}$ & $14.02 \mathrm{a}$ & $13.79 \mathrm{a}$ & $14.84 \mathrm{a}$ & $20.01 \mathrm{a}$ & $20.29 a$ & $19.28 \mathrm{a}$ \\
\hline ME kcal $\left(\mathrm{kg} \mathrm{BW}^{-0.75}\right)$ & $116.6 \mathrm{~b}$ & $114.5 \mathrm{~b}$ & $120.2 \mathrm{a}$ & $146.6 \mathrm{a}$ & $145.0 \mathrm{a}$ & $148.8 \mathrm{a}$ & $198.6 \mathrm{a}$ & $200.0 \mathrm{a}$ & $198.5 \mathrm{a}$ \\
\hline
\end{tabular}

${ }^{(1)}$ The effect of dietary intake on dry matter, total protein, fibrous fraction, and metabolizable energy by Holstein, Gyrolando F1, and Gyr heifers. 
( $\mathrm{g} \mathrm{kg}^{-1} \mathrm{BW}^{-0.75}$ ); and $\mathrm{ME}$ in Mcal per day and kcal $\left(\mathrm{kg} \mathrm{BW}^{-0.75}\right)$, regardless of the breed composition group evaluated (Table 4). The results presented high and close coefficients of determination for both models. The coefficient of determination $\left(\mathrm{R}^{2}\right)$, considered in isolation, is not an adequate criterion for the discussion of model fit, since, in nonlinear models, it is common to obtain asymptotic and high $\mathrm{R}^{2}$ values with little variation (Cerrato \& Blackmer, 1990). As to the choice of the best model, it is preferable to opt for the nonlinear model, due to its greater practicality related to the ease of interpretation of parameters $a$ and $b$.

The interaction between the nutritional plan and breed composition group for the digestibility coefficients was significant only for EE (Table 5). In the nutritional plan with 11 and $14 \mathrm{~g} \mathrm{~kg}^{-1}$, Holstein, Gyr and Gyrolando F1 heifers did not differ regarding EE digestibility. For the $19-\mathrm{g} \mathrm{kg}^{-1}$ plan, Gyr heifers presented EE digestibility similar to that of Holstein heifers $\left(870.28\right.$ vs $\left.828.96 \mathrm{~g} \mathrm{~kg}^{-1}\right)$; and these values were $13.85 \%$ higher than that of the Gyrolando F1 heifers $\left(764.39 \mathrm{~g} \mathrm{~kg}^{-1}\right)$. This variation of $13.85 \%$ in EE digestibility was higher than that observed by Rennó et al. (2005), who reported a $6.8 \%$ variation in EE utilization, in steers of different genetic groups (Holstein, $1 / 2$ Holstein $\times$ Guzerá, $1 / 2$ Holstein $\times$ Gyr, and pure Zebu). Beecher et al. (2014) found variations of 2.3, 2,8, and $3 \%$, for DM, organic matter, and NDF digestibility in Jersey, crossbred Jersey $\times$ Holstein $\times$ Friesian, and Holstein $\times$ Friesian cows fed perennial ryegrass. The authors attributed the superiority of the Jersey animals, in the evaluated digestive parameters, to their relatively larger gastrointestinal tract (GIT), as well as to the higher frequency and number of chews and rumination (Prendiville et al., 2010).

The increase in the relative size of the GIT indicates that there will be greater area available for nutrient absorption, which will allow greater absorption of nutrients and, therefore, increase the digestibility (Van Soest, 1994). Chewing already plays a physical role in the digestion of feed (McAllister et al., 1994). In the present study, the frequency and time spent in the intake process, and the size and weight of the organs of the GIT were not evaluated. Therefore, the digestibility of the nutrients cannot be inferred from the isolated effect of the genetic base of the animals. For this reason, it is suggested that the measurement of these parameters be done in future studies to

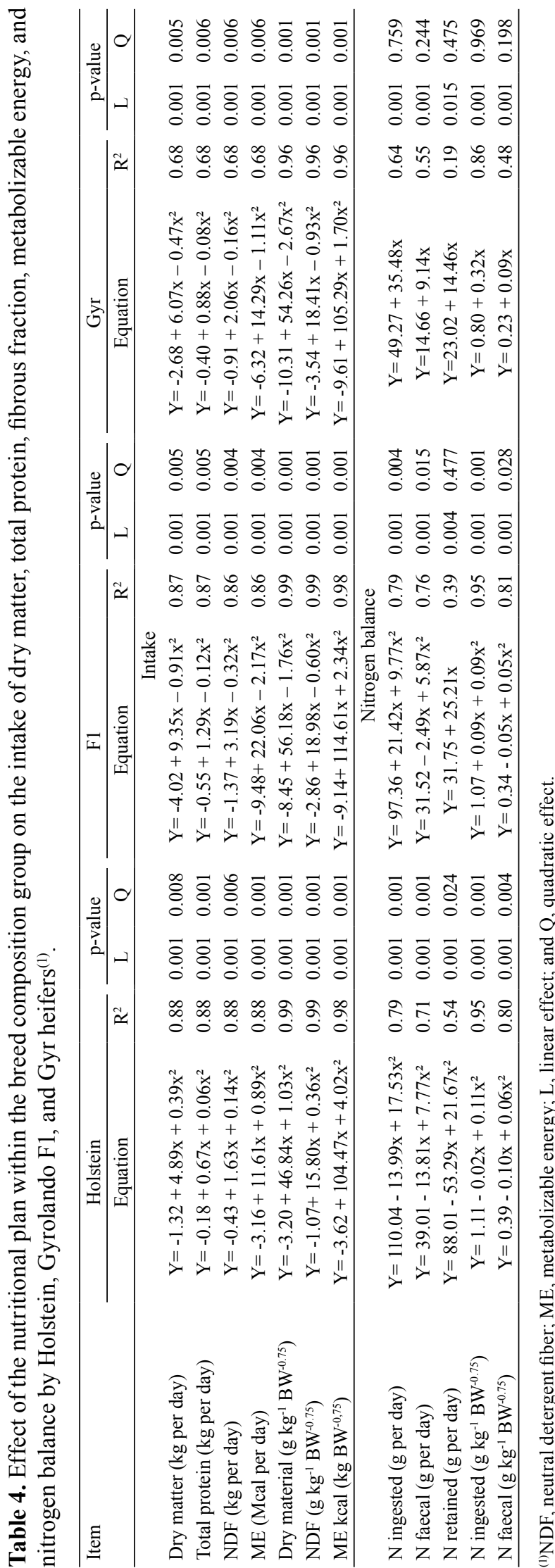

Pesq. agropec. bras., Brasília, v.53, n.2, p.247-255, Feb. 2018 DOI: $10.1590 / \mathrm{S} 0100-204 X 2018000200014$ 
verify the magnitude of the effect of genotypes on the digestibility of diet components.

The breed composition groups responded differently to the nutritional plan used, with respect to the EE digestibility coefficient. This variable decreased linearly with the increase in diet supply $(\mathrm{Y}=925.89-90.93 \mathrm{x}, \mathrm{p}=0.002)$ in Gyrolando $\mathrm{F} 1$ heifers (Table 6). In Gyr heifers, a quadratic response was observed $\left(\mathrm{Y}=-1,402.61-826.81 \mathrm{x}+271.66 \mathrm{x}^{2}\right.$, $\mathrm{p}=0.034)$; and, in Holstein heifers, there was no linear or quadratic adjustment, with an average value of 810.27 $\mathrm{g} \mathrm{kg}^{-1}$. It is expected that digestibility decrease with the increase in DM intake due to the higher passage rate and the lower retention time of the nutrients by the rumen microorganisms (NRC, 2001). Similarly, lower $\mathrm{DM}$ intake is generally associated with greater nutrient use (NRC, 2001).

The interaction between the nutritional plan and breed composition group was significant for the retained
$\mathrm{N}$ (g per day), but the effect of breed composition group was not significant within each nutritional plan (Table 7). This result suggests that the breed composition of the animals does not interfere with $\mathrm{N}$ balance. In the 11 and 14-g kg ${ }^{-1}$ plans, DM intake and faecal excretion of $\mathrm{N}$ ( $\mathrm{g}$ per day and $\mathrm{g} \mathrm{kg}^{-1} \mathrm{BW}^{-0.75}$ ) did not differ among the different breed composition groups evaluated. However, for the 19-g kg-1 plan, Gyrolando F1 and Holstein heifers presented higher intake (14.35\%) and excretion (19.16\%) of $\mathrm{N}$ compared with Gyr heifers.

The lower values of DM intake and faecal $\mathrm{N}$ excretion by Gyr heifers in the $19-\mathrm{g} \mathrm{kg}^{-1}$ plan, in addition to the similar $\mathrm{N}$ values (g per day), indicate that Zebu cattle seem to be more efficient in the use of dietary $\mathrm{N}$. This probably resulted in greater $\mathrm{N}$ recycling under nutritional plans with greater availability of nutrients, since the pool of urea in the metabolism is under physiological homeostatic control and tends to remain constant, according to Van Soest (1994).

Table 5. Nutrient and gross energy digestibility coefficients for Holstein, Gyrolando F1, and Gyr heifers subjected to nutritional plans, with different nutrient availibility ${ }^{(1)}$.

\begin{tabular}{|c|c|c|c|c|c|c|c|c|c|c|}
\hline \multirow[t]{2}{*}{ Item } & \multicolumn{3}{|c|}{ Nutritional plan $\left(\mathrm{g} \mathrm{kg}^{-1}\right)$} & \multicolumn{3}{|c|}{ Breed composition } & \multirow[t]{2}{*}{ SEM } & \multicolumn{3}{|c|}{ p-value } \\
\hline & 11 & 14 & 19 & Holstein & F1 & Gyr & & NP & $\mathrm{BC}$ & $\mathrm{NP} \times \mathrm{BC}$ \\
\hline Dry matter $\left(\mathrm{g} \mathrm{kg}^{-1}\right)$ & 713.00 & 704.61 & 701.25 & 712.72 & 702.88 & 703.41 & 3.1439 & 0.303 & 0.363 & 0.097 \\
\hline Organic matter $\left(\mathrm{g} \mathrm{kg}^{-1}\right)$ & 737.96 & 727.87 & 720.50 & 733.28 & 725.52 & 727.54 & 3.1063 & 0.076 & 0.554 & 0.059 \\
\hline Gross energy $\left(\mathrm{g} \mathrm{kg}^{-1}\right)$ & 719.17 & 708.54 & 701.95 & 713.77 & 704.68 & 711.20 & 3.2299 & 0.101 & 0.562 & 0.065 \\
\hline Crude protein $\left(\mathrm{g} \mathrm{kg}^{-1}\right)$ & 721.96 & 712.35 & 702.61 & 707.40 & 704.55 & 724.98 & 3.5741 & 0.102 & 0.290 & 0.073 \\
\hline $\mathrm{NDF}\left(\mathrm{g} \mathrm{kg}^{-1}\right)$ & 491.57 & 478.20 & 485.31 & 490.25 & 490.17 & 474.66 & 6.1737 & 0.682 & 0.752 & 0.674 \\
\hline Ether extract $\left(\mathrm{g} \mathrm{kg}^{-1}\right)$ & 860.96 & 858.76 & 821.21 & 834.21 & 819.05 & 871.55 & 6.5521 & 0.014 & 0.073 & 0.019 \\
\hline $\mathrm{NFC}\left(\mathrm{g} \mathrm{kg}^{-1}\right)$ & 920.98 & 913.84 & 896.87 & 919.03 & 908.68 & 903.98 & 3.3523 & $0.010_{\mathrm{L}}$ & 0.187 & 0.126 \\
\hline
\end{tabular}

(1)SEM, standard error of the mean; NP, nutritional plan; BC, breed composition group; NDF, neutral detergent fiber; and NFC, non-fibrous carbohydrates $(\mathrm{y}=975.21-35.86 \mathrm{x})$

Table 6. Nitrogen balance in Holstein, Gyrolando F1, and Gyr heifers subjected to nutritional plans, with different nutrient availibility.

\begin{tabular}{|c|c|c|c|c|c|c|c|c|c|c|}
\hline \multirow[t]{2}{*}{ Item } & \multicolumn{3}{|c|}{ Nutritional plan $\left(\mathrm{g} \mathrm{kg}^{-1}\right)$} & \multicolumn{3}{|c|}{ Breed composition } & \multirow[t]{2}{*}{ SEM } & \multicolumn{3}{|c|}{$\mathrm{p}$-value } \\
\hline & 11 & 14 & 19 & Holstein & F1 & Gyr & & NP & $\mathrm{BC}$ & $\mathrm{NP} \times \mathrm{BC}$ \\
\hline Ingested $\mathrm{N}\left(\mathrm{g} \mathrm{kg}^{-1}\right)$ & 89.22 & 123.49 & 177.81 & 131.73 & 132.12 & 126.67 & 5.5030 & 0.001 & 0.419 & 0.001 \\
\hline Faecal $\mathrm{N}\left(\mathrm{g} \mathrm{kg}^{-1}\right)$ & 27.39 & 37.75 & 55.77 & 41.62 & 42.47 & 36.82 & 1.8156 & 0.001 & 0.114 & 0.001 \\
\hline Urine $\mathrm{n}\left(\mathrm{g} \mathrm{kg}^{-1}\right)^{(1)}$ & 20.46 & 30.66 & 39.18 & 23.17 & 35.29 & 31.53 & 2.5898 & $0.009^{*}$ & 0.110 & 0.223 \\
\hline Retained N $\left(\mathrm{g} \mathrm{kg}^{-1}\right)$ & 49.01 & 64.82 & 86.06 & 72.71 & 61.90 & 65.28 & 3.5173 & 0.001 & 0.111 & 0.031 \\
\hline Ingested $\mathrm{N}\left(\mathrm{g} \mathrm{kg}^{-1} \mathrm{BW}^{-0,75}\right)$ & 1.13 & 1.45 & 1.91 & 1.53 & 1.43 & 1.52 & 0.0351 & 0.001 & 0.003 & 0.001 \\
\hline Faecal N $\left(\mathrm{g} \mathrm{kg}^{-1} \mathrm{BW}^{-0,75}\right)$ & 0.33 & 0.43 & 0.59 & 0.47 & 0.48 & 0.41 & 0.0130 & 0.001 & 0.024 & 0.001 \\
\hline Urine $\mathrm{N}\left(\mathrm{g} \mathrm{kg}^{-1} \mathrm{BW}^{-0,75}\right)^{(2)}$ & 0.31 & 0.41 & 0.48 & 0.34 & 0.46 & 0.41 & 0.0236 & $0.021^{*}$ & 0.118 & 0.243 \\
\hline Retained N ( $\left.\mathrm{kg} \mathrm{BW}^{-0,75}\right)^{(3)}$ & 0.56 & 0.68 & 0.92 & 0.80 & 0.67 & 0.69 & 0.0292 & $0.001 *$ & 0.088 & 0.098 \\
\hline
\end{tabular}

${ }^{(1)} \mathrm{Y}_{\text {Urine N }}=17.74+11.13 \mathrm{x} .{ }^{(2)} \mathrm{Y}_{\text {Urine N }}=0.2398+0.08 \mathrm{x} \cdot{ }^{(3)} \mathrm{Y}_{\text {Retained N }}=0.340+0.187 \mathrm{x}$. SEM, standard error of the mean; NP, nutritional plan; and BC, breed composition group. *Significant linear effect at $5 \%$ probability. 
The values of metabolizable protein for the maintenance of 1.72 and $4.28 \mathrm{~g} \mathrm{~kg}^{-1} \mathrm{BW}^{-0.75}$ for Nellore and Holstein steers, respectively, obtained by Ezequiel (1987), suggest that the loss through excretion of endogenous metabolites in Nellore cattle (Bos indicus) is lower than that of Holstein cattle (Bos taurus). This would be in alignment with the findings of the present study, in which a lower faecal excretion of $\mathrm{N}\left(\mathrm{g} \mathrm{kg}^{-1}\right.$ $\mathrm{BW}^{-0.75}$ ) in Gyr animals was observed (Table 7).

The variation of 17 and $38 \%$ for ingested and faecal $\mathrm{N}\left(\mathrm{g} \mathrm{kg}^{-1} \mathrm{BW}^{-0.75}\right)$, respectively, was lower than the 32.9 and $46.3 \%$ variation reported by Pancoti (2015) in Holstein, Gyr and Gyrolando, fed the same diet. This can be attributed to the lower variation in CP intake, which, in the present study, was up to $4.65 \%$, while in Pancoti (2015) it was $38.2 \%$.

The losses of urinary $\mathrm{N}$ (g per day and $\mathrm{g} \mathrm{kg}^{-1} \mathrm{BW}^{-0.75}$ ) were affected by the nutritional plan used (Table 6), which is in agreement with Higgs et al. (2012), who found that this variable is associated with $\mathrm{N}$ intake. Protein intake and $\mathrm{N}$ excretion by faeces and urine present high correlation (Sinclair et al., 2014). Increased $\mathrm{N}$ excretion in the urine due to increased $\mathrm{CP}$ ingestion (Table 4) and rapid ruminal degradation of $\mathrm{N}$ leads to ammonia production greater than the microbial demand for the nutrient in the rumen. This excess ammonia is absorbed in the rumen and converted to urea in the liver, and results in increased plasmatic urea concentration. As the excess of $\mathrm{N}$ excreted in the urine is not desirable from the economic and environmental point of view, restrictive nutritional plans that do not cause great impact on animal performance are highly desirable.

When the breed composition group was analyzed separately, N losses presented some disparity with the values reported in the literature (Rennó et al., 2008). When different breed composition groups were subjected to the same diet and the same nutritional plan, it was verified that losses of endogenous $\mathrm{N}$ ( $\mathrm{mmol}$ $\mathrm{kg}^{-1} \mathrm{BW}^{-0.75}$ ) for Zebu were lower than those for Bos taurus animals (Rennó et al., 2008). This suggests that Zebu animals are more efficient in the use of $\mathrm{N}$ than Taurine breeds. In the present study, the breed composition group had no effect on $\mathrm{N}$ losses via urine (g per day and $\mathrm{g} \mathrm{kg}^{-1} \mathrm{BW}^{-0.75}$ ) (Table 6).

The quadratic response observed for the intake of DM and nutrients according to the nutritional plan (Table 4) was also verified for faecal intake and excretion of $\mathrm{N}$ for Holstein and Gyrolando F1 heifers. However, for Gyr heifers, there was an increasing linear response to DM intake and faecal excretion of $\mathrm{N}$.

The ADG was affected by the nutritional plan (Table 8), regardless of the breed composition group evaluated, and increased linearly with the increase of

Table 7. Sliced interaction of the breed composition group within the nutritional plan, regarding nitrogen balance in Holstein, Gyrolando F1, and Gyr heifers ${ }^{(1)}$.

\begin{tabular}{|c|c|c|c|c|c|c|c|c|c|}
\hline \multirow{2}{*}{ Item } & \multicolumn{3}{|c|}{$11 \mathrm{~g} \mathrm{~kg}^{-1}$} & \multicolumn{3}{|c|}{$14 \mathrm{~g} \mathrm{~kg}^{-1}$} & \multicolumn{3}{|c|}{$19 \mathrm{~g} \mathrm{~kg}^{-1}$} \\
\hline & Holstein & F1 & Gyr & Holstein & F1 & Gyr & Holstein & F1 & Gyr \\
\hline Ingested $\mathrm{N}\left(\mathrm{g} \mathrm{kg}^{-1}\right)$ & $87.05 \mathrm{a}$ & $83.23 \mathrm{a}$ & $97.37 \mathrm{a}$ & $121.47 \mathrm{a}$ & $123.37 \mathrm{a}$ & $125.62 \mathrm{a}$ & $186.66 \mathrm{a}$ & $189.75 \mathrm{a}$ & $157.01 \mathrm{~b}$ \\
\hline Faecal $N\left(\mathrm{~g} \mathrm{~kg}^{-1}\right)$ & $28.32 \mathrm{a}$ & $25.56 \mathrm{a}$ & $28.28 \mathrm{a}$ & $36.77 \mathrm{a}$ & $37.98 \mathrm{a}$ & $38.51 \mathrm{a}$ & $59.78 \mathrm{a}$ & $63.87 \mathrm{a}$ & $43.67 \mathrm{~b}$ \\
\hline Retained N ( $\left.\mathrm{g} \mathrm{kg}^{-1}\right)$ & $50.14 \mathrm{a}$ & $37.73 \mathrm{a}$ & $55.63 \mathrm{a}$ & $59.49 \mathrm{a}$ & $64.98 \mathrm{a}$ & $60.96 \mathrm{a}$ & $110.2 \mathrm{a}$ & $79.88 \mathrm{a}$ & $78.10 \mathrm{a}$ \\
\hline Ingested $\mathrm{N}\left(\mathrm{g} \mathrm{kg}^{-1} \mathrm{BW}^{-0,75}\right)$ & $1.13 \mathrm{a}$ & $1.13 \mathrm{a}$ & $1.12 \mathrm{a}$ & $1.45 \mathrm{a}$ & $1.47 \mathrm{a}$ & $1.43 \mathrm{a}$ & $1.99 \mathrm{a}$ & $1.99 \mathrm{a}$ & $1.74 b$ \\
\hline Faecal $N\left(\mathrm{~g} \mathrm{~kg}^{-1} \mathrm{BW}^{-0,75}\right)$ & $0.35 \mathrm{a}$ & $0.34 \mathrm{a}$ & $0.31 \mathrm{a}$ & $0.43 \mathrm{a}$ & $0.44 \mathrm{a}$ & $0.43 \mathrm{a}$ & $0.62 \mathrm{a}$ & $0.65 \mathrm{a}$ & $0.48 \mathrm{~b}$ \\
\hline
\end{tabular}

(1)Means followed by equal letters, in the comparison of breed composition groups in each nutritional plan, do not differ by Tukey's test, at $5 \%$ probability.

Table 8. Performance of Holstein, Gyrolando F1, and Gyr heifers subjected to different nutritional plans in relation to body weight $^{(1)}$.

\begin{tabular}{|c|c|c|c|c|c|c|c|c|c|c|}
\hline \multirow{2}{*}{ Item } & \multicolumn{3}{|c|}{ Nutritional plan $\left(\mathrm{g} \mathrm{kg}^{-1}\right)$} & \multicolumn{3}{|c|}{ Breed composition group } & \multirow{2}{*}{ SEM } & \multicolumn{3}{|c|}{$\mathrm{p}$-value } \\
\hline & 11 & 14 & 19 & Holstein & F1 & Gyr & & NP & $\mathrm{BC}$ & $\mathrm{NP} \times \mathrm{BC}$ \\
\hline Initial BW (kg) & 369.58 & 390.25 & 402.79 & 402.88 & 456.79 & 302.96 & - & - & - & - \\
\hline ADG (kg per dia) & 0.398 & 0.629 & 0.800 & 0.605 & 0.636 & 0.585 & 0.0369 & $0.001 *$ & 0.783 & 0.584 \\
\hline Feed efficiency $\left(\mathrm{FE}, \mathrm{kg} \mathrm{kg}^{-1}\right)$ & 0.084 & 0.104 & 0.099 & 0.090 & 0.099 & 0.097 & 0.0031 & 0.059 & 0.511 & 0.831 \\
\hline
\end{tabular}

(1)SEM, standard error of the mean; NP, nutritional plan; BC, breed composition group; BW, body weight; and ADG, average daily weight gain $($ YGMD $=-0.199+0.556 x)$. 
diet supply. Despite the differences in the intake of DM and nutrients among Holstein, Gyrolando F1, and Gyr heifers, the breed composition group did not affect ADG. Feed efficiency also did not differ between Holstein, Gyrolando F1, and Gyr heifers, nor between the nutritional plans.

The results of animal performance in the present study showed that the recommendations proposed by NRC (2001) for feeding of heifers of the Holstein breed, with $370 \mathrm{~kg}$, also allow weight gains of $800 \mathrm{~g}$ per day for Zebu and crossbreed heifers subjected to a nutritional plan of higher DM and nutrient intake (19 $\left.\mathrm{g} \mathrm{kg}^{-1}\right)$. In the absence of nutritional recommendations for the formulation of diets for dairy haifers raised in tropical conditions, these findings may be more appropriate for crossbred females, since NRC (2000) suggests that Bos taurus animals need more energy for maintenance and weight gain than the Bos indicus, with intermediate values for net energy requirements for the maintenance of crossbred animals (NRC, 2001).

\section{Conclusions}

1. The nutritional plans show a quadratic response to nutrient intake and a linear response to average daily gain, but do not affect the digestibility coefficients.

2. In tropical conditions, Zebu (Gyr) and crossbred dairy heifers (Gyrolando F1) subjected to nutritional plans with more or less feed supply show nutritional efficiency similar to that of Holstein heifers.

\section{Acknowledgments}

To Empresa Brasileira de Pesquisa Agropecuária (Embrapa), to Conselho Nacional de Desenvolvimento Científico e Tecnológico (CNPq), to Fundação de Amparo à Pesquisa do Estado de Minas Gerais (Fapemig), and to Coordenação de Aperfeiçoamento de Pessoal de Nível Superior (Capes), for financial support.

\section{References}

BEECHER, M.; BUCKLEY, F.; WATERS, S.M.; BOLAND, T.M.; ENRIQUEZ-HIDALGO, D.; DEIGHTON, M.H.; O'DONOVAN, M.; LEWIS, E. Gastrointestinal tract size, total-tract digestibility, and rumen microflora in different dairy cow genotypes. Journal of Dairy Science, v.97, p.3906-3917, 2014. DOI: 10.3168/jds.20137708 .
BROUWER, E. Report of sub-committee on constants and factors. In: SYMPOSIUM ON ENERGY METABOLISM, $3^{\text {rd }}, 1964$, Scotland. Proceedings... London: Academic Press, 1965. p.441-443. (European Association for Animal Production. Publication $\mathrm{n}^{\mathrm{o}}$ 11).

CERRATO, M.E.; BLACKMER, A.M. Comparison of models for describing; corn yields response to nitrogen fertilizer. Agronomy Journal, v.82, p.138-143, 1990. DOI: 10.2134/agronj1990.000219 62008200010030x.

COLLARD, B.L.; BOETTCHER, P.J.; DEKKERS, J.C.M.; PETITCLERC, D.; SCHAEFFER, L.R. Relationship between energy balance and health traits of dairy cattle in early lactation. Journal of Dairy Science, v.83, p.2683-2690, 2000. DOI: 10.3168/ jds.S0022-0302(00)75162-9.

CUNNIFF, P. (Ed.). Official methods of analysis of AOAC International. $16^{\text {th }}$ ed. Washington: Association of Official Analytical Chemistry, 1995. v. 1.

EZEQUIEL, J.M.B. Exigências de proteína e minerais de bovídeos: frações endógenas. 1987. 131p. Tese (Doutorado) Universidade Federal de Viçosa, Viçosa.

FOX, D.G.; SNIFFEN, C.J.; O'CONNOR, J.D. Adjusting nutrient requirements of beef cattle for animal and environmental variations. Journal of Animal Science, v.66, p.1475-1495, 1988. DOI: $10.2527 /$ jas 1988.6661475x.

GALYEAN, M.L.; HUBBERT, M.E. Predicting intake by beef cattle: relationship of dry matter intake to initial weight. New Mexico: Agricultural Experiment Statiom, 1992. (Clayton Livestock Research Center Report, $\mathrm{n}^{\mathrm{o}} 80$ ).

HELRICH, K. (Ed.). Official methods of analysis of the Association of Official Analytical Chemist. $15^{\text {th }}$ ed. Arlington: Association of Official Analytical Chemists, 1990. 1117p.

HIGGS, R.J.; CHASE, L.E.; VAN AMBURGH, M.E. Development and evaluation of equations in the Cornell Net Carbohydrate and Protein System to predict nitrogen excretion in lactating dairy cows. Journal of Dairy Science, v.95, p.2004-2014, 2012. DOI: 10.3168/jds.2011-4810.

LICITRA, G.; HERNANDEZ, T.M.; VAN SOEST, P.J. Standardization of procedures for nitrogen fractionation of ruminant feeds. Animal Feed Science and Technology, v.57, p.347- 358, 1996. DOI: 10.1016/0377-8401(95)00837-3.

MACHADO, F.S.; TOMICH, T.R.; FERREIRA, A.L.; CAVALCANTI, L.F.L.; CAMPOS, M.M.; PAIVA, C.A.V.; RIBAS, M.N.; PEREIRA, L.G.R. Technical note: a facility for respiration measurements in cattle. Journal of Dairy Science, v.99, p.1-8, 2016. DOI: 10.3168/jds.2015-10298.

MCALLISTER, T.A.; BAE, H.D.; JONES, G.A.; CHENG, K.J. Microbial attachment and feed digestion in the rumen. Journal of Animal Science, v.72, p.3004-3018, 1994. DOI: 10.2527/1994.72113004x.

MERTENS, D.R. Gravimetric determination of amylase-treated neutral detergent fiber in feeds with refluxing in beaker or crucibles: collaborative study. Journal of AOAC International, v.85, p.1217-1240, 2002. 
NRC. National Research Council. Nutrient requirements of beef cattle. $7^{\text {th }}$ ed. Washington: National Research Council, 2000. 249 p.

NRC. National Research Council. Nutrient requirements of dairy cattle. $7^{\text {th }}$ rev. ed. Washington: National Research Council, 2001. 381p.

PANCOTI, C.G. Exigências nutricionais de energia de novilhas Gir, Holandês e F1 - Holandês x Gir. 2015. 121p. Tese (Doutorado) - Universidade Federal de Minas Gerais, Belo Horizonte.

PRENDIVILLE, R.; LEWIS, E.; PIERCE, K.M.; BUCKLEY, F. Comparative grazing behavior of lactating Holstein-Friesian, Jersey, and Jersey $\times$ Holstein-Friesian dairy cows and its association with intake capacity and production efficiency. Journal of Dairy Science, v.93, p.764-774, 2010. DOI: 10.3168/jds.2009-2659.

RENNÓ, L.N.; VALADARES FILHO, S. de C.; PAULINO, M.F.; LEÃO, M.I.; VALADARES, R.F.D.; RENNÓ, F.P.; PAIXÃO, M.L. Níveis de uréia na ração de novilhos de quatro grupos genéticos: parâmetros ruminais, uréia plasmática e excreções de uréia e creatinina. Revista Brasileira de Zootecnia, v.37, p.556562, 2008. DOI: 10.1590/S1516-35982008000300022.

RENNÓ, L.N.; VALADARES FILHO, S. de C.; VALADARES, R.F.D.; CECON, P.R.; BACKES, A.A.; RENNÓ, F.P.; ALVES, D.D.; SILVA, P.A. Níveis de uréia na ração de novilhos de quatro grupos genéticos: consumo e digestibilidades totais. Revista Brasileira de Zootecnia, v.34, p.1775-1785, 2005. DOI: 10.1590/ S1516-35982005000500039.

ROTTA, P.P.; VALADARES FILHO, S.C.; DETMANN, E.; COSTA E SILVA, L.F.; PAULINO, M.F.; MARCONDES, M.I.; LOBO, A.A.G.; VILLADIEGO, F.A.C. Digesta sampling sites and marker methods for estimation of ruminal outflow in bulls fed different proportions of corn silage or sugar cane. Journal of Animal Science, v.92. p.2996-3006, 2014. DOI: 10.2527/jas.2013-7364.

SILVA, M.V.G.B.; MARTINS, M.F.; CEMBRANELLI, M. de A.R.; PANETTO, J.C. do C.; FREITAS, A.F. de; PAIVA, L. de C.; GONÇALVES, G.S.; ALVES, B.R.C. Programa de melhoramento genético da raça girolando - avaliação genética de vacas - junho/2016. Juiz de Fora: Embrapa Gado de Leite, 2016. 40p. (Embrapa Gado de Leite. Documentos, 192).

SINCLAIR, K.D.; GARNSWORTHY, P.C.; MANN, G.E.; SINCLAIR, L.A. Reducing dietary protein in dairy cow diets: implications for nitrogen utilization, milk production, welfare and fertility. Animal, v.8, p.262-274, 2014. DOI: 10.1017/ S1751731113002139.

VALADARES FILHO, S.C; COSTA E SILVA, L.F.; GIONBELLI, M.P.; ROTTA, P.P.; MARCONDES, M.I.; CHIZZOTTI, M.L.; PRADOS, L.F. Exigências nutricionais de zebuínos puros e cruzados: BR-CORTE. 3.ed. Viçosa: Ed. da UFV, 2016. p.163-190.

VALADARES, R.F.D.; GONCALVES, L.C.; RODRÍGUEZ, N.M.; SAMPAIO, I.B.; VALADARES FILHO, S.C. Metodologia de coleta de urina em vacas utilizando sondas de Folley. Revista Brasileira de Zootecnia, v.26, p.1279-1282, 1997.

VAN SOEST, P.J. Nutritional ecology of the ruminant. $2^{\text {nd }}$ ed. Ithaca: Cornell University Press, 1994. 476p.

VAN SOEST, P.J.; ROBERTSON, J.B.; LEWIS, B.A. Methods for dietary fiber, neutral detergent fiber, and nonstarch polysaccharides in relation to animal nutrition. Journal of Dairy Science, v.74, p.3583-3597, 1991. DOI: 10.3168/jds.S0022-0302(91)78551-2.

WALDO, D.R.; JORGENSEN, N.A. Forages for high animal production: nutritional factors and effects of conservation. Journal of Dairy Science, v.64, p.1207-1229, 1981. DOI: 10.3168/ jds.S0022-0302(81)82697-5.

Received on December 16, 2016 and accepted on June 22, 2017

Pesq. agropec. bras., Brasília, v.53, n.2, p.247-255, Feb. 2018 